\title{
Pour une anthropologie expérimentale : l'étude des techniques
}

\section{Stephen Beckerman}

\section{(2) OpenEdition}

1 Journals

Édition électronique

URL : https://journals.openedition.org/tc/962

DOI : $10.4000 /$ tc.962

ISSN : 1952-420X

Éditeur

Éditions de l'EHESS

\section{Édition imprimée}

Date de publication : 1 juin 1985

ISSN : 0248-6016

\section{Référence électronique}

Stephen Beckerman, « Pour une anthropologie expérimentale : l'étude des techniques », Techniques \& Culture [En ligne], 5 | 1985, mis en ligne le 25 janvier 2006, consulté le 29 septembre 2022. URL : http:// journals.openedition.org/tc/962; DOI : https://doi.org/10.4000/tc.962

Ce document a été généré automatiquement le 29 septembre 2022.

Tous droits réservés 
Pour une anthropologie expérimentale : l'étude des techniques

Stephen Beckerman 